\title{
Benzyl Isothiocyanate Induces Apoptotic Cell Death Through Mitochondria-dependent Pathway in Gefitinib-resistant NCI-H460 Human Lung Cancer Cells In Vitro
}

\author{
YI-PING HUANG ${ }^{1}$, YI-WEN JIANG ${ }^{2}$, HSIN-YU CHEN ${ }^{2}$, YUNG-TING HSIAO ${ }^{2}$, SHU-FEN PENG ${ }^{2}$, \\ YU-CHENG CHOU ${ }^{3,4}$, JIUN-LONG YANG ${ }^{2}$, TE-CHUN HSIA ${ }^{5,6^{*}}$ and JING-GUNG CHUNG ${ }^{2,7 *}$ \\ ${ }^{1}$ Department of Physiology, College of Medicine, and Departments of ${ }^{2}$ Biological Science and Technology, and \\ ${ }^{5}$ Respiratory Therapy, China Medical University, Taichung, Taiwan, R.O.C.; \\ ${ }^{3}$ Division of Neurosurgical Oncology, Neurological Institute, \\ Taichung Veterans General Hospital, Taichung, Taiwan, R.O.C.; \\ ${ }^{4}$ School of Medicine, National Defense Medical Center, Taipei, Taiwan, R.O.C.; \\ ${ }^{6}$ Department of Internal Medicine, China Medical University Hospital, Taichung, Taiwan, R.O.C.; \\ ${ }^{7}$ Department of Biotechnology, Asia University, Taichung, Taiwan, R.O.C.
}

\begin{abstract}
Background/Aim: Gefitinib is used to treat patients with lung cancer, but in some patients, the disease becomes gefitinib-resistant. Benzyl isothiocyanate (BITC), found in cruciferous vegetables, has shown anticancer activity in many human cancer cell lines. However, the effects of BITC on gefitinib-resistant NCI-H460 lung cancer cells in vitro have not been investigated. Materials and Methods: The effects of BITC on gefitinib-resistant NCIH460 lung cancer cells were investigated in vitro. Flow cytometric assay was used for determining the total viable cell number, apoptotic cell death, the production of reactive oxygen species (ROS) and $\mathrm{Ca}^{2+}$, mitochondrial membrane potential $\left(\Psi_{m}\right)$ and caspase-3, -8 and -9 activities. Furthermore, 4', 6-diamidino-2-phenylindole staining was used to examine chromatin condensation in NCI-H460 and NCI-H460/G cells. Results: BITC reduced total viable cell number via the induction of apoptotic cell death, that was also confirmed by annexin V/propidium iodide double staining assay. BITC increased ROS and $\mathrm{Ca}^{2+}$ production,
\end{abstract}

*These Authors contributed equally to this study.

Correspondence to: Professor Jing-Gung Chung, Department of Biological Science and Technology, China Medical University, No 91, Hsueh-Shih Road, Taichung, Taiwan, R.O.C. Tel: +886 422053366, ext. 8000, Fax: +886 422053764, e-mail: jgchung@mail.cmu.edu.tw; Dr. Te-Chun Hsia, Department of Respiratory Therapy, China Medical University, No 91, Hsueh-Shih Road, Taichung, Taiwan, R.O.C.E-mail: hsiatc@mail.cmu.edu.tw

Key Words: Benzyl isothiocyanate, gefitinib-resistant, human lung cancer, mitochondria-dependent pathway. reduced $\Psi_{m}$ and increased caspase-3, -8 and -9 activities in both NCI-H460 and NCI-H460/G cells. Western blotting assay also showed that BITC increased expression of cleaved caspase-3 and -9, cytochrome c, BCL2-associated X protein, endonuclease $G$, poly (ADP-ribose) polymerase, growth arrest and DNA-damage protein 153, caspase-7 and activating transcription factor 6 alpha, but reduced apoptosis-inducing factor and caspase-9, BH3-interacting domain death agonist, calpain 1, glucose-regulated protein 78 and inositol requiring enzyme 1 alpha in NCI-H460/G cells. Conclusion: BITC-induced apoptotic cell death appears to occur via caspase-and mitochondria-dependent pathways in both cell lines.

Worldwide, it has been recognized that lung cancer remains the leading cause of cancer-related deaths, and the most common form $(>80 \%)$ of lung cancer is non-small cell lung cancer (NSCLC) (1). Chemotherapy for patients with cancer can lead to tumor remission, but may also result in the development of drug resistance and the mechanism of such resistance has been studied (2). Gefitinib (IRESSA ${ }^{\circledR}$, AstraZeneca), an inhibitor of the epidermal growth factor receptor (EGFR) $(3,4)$, was demonstrated to have significant antitumor activity in patients with advanced NSCLC with EGFR mutations $(5,6)$. After treatment with this drug, some patients develop resistance (7). Currently, some agents are used that simultaneously block mesenchymal transition and smoothened and can overcome gefitinib-resistance in human NSCLC (8).

Benzyl isothiocyanate (BITC), a compound found in cruciferous vegetables, was found to induce cytotoxic effects via the induction of cancer cell apoptosis in many human 
cancer cell lines (9-13). Our previous studies also showed that BITC alters the expression of genes associated with cellcycle regulation and apoptotic cell death in GBM 8401 human brain glioblastoma cells in vitro (14). It was also shown that BITC suppressed the metastatic potential of highly metastatic lung cancer cells through the induction of apoptosis and cell-cycle arrest, via targeting the mitogenactivated protein kinase/activation protein transcription factor 1 (MAPK/AP1) pathway (15). Oral BITC treatment induced a significant reduction in the growth of solid breast tumors and reduced the numbers of pulmonary tumor nodules and total pulmonary metastatic volume in BALB/c mice (16). Recently, it was reported that BITC inhibited the growth of gefitinib-resistant human lung adenocarcinoma cells (PC9/AB2 and PC9/BB4 cells) by inducing apoptosis in a dose-dependent manner, and activating caspase- 3 and protein kinase B (AKT)/MAPK pathways with generation of reactive oxygen species (17).

Although numerous studies have shown that BITC induced apoptosis of human cancer cells, including lung cancer cells and gefitinib-resistant human lung cancer cells, however, to our knowledge, there is no report on NCI-H460 gefitinibresistant cell lines in vitro. Therefore, we investigated the effects of BITC on gefitinib-resistant human lung cancer cells.

\section{Materials and Methods}

Test compound and reagents. BITC, propidium iodide (PI), Tris- $\mathrm{HCl}$, trypsin, trypan blue, dimethyl sulfoxide (DMSO) and 4',6-diamidino2-phenylindole (DAPI) were purchased from Sigma Chemical Co. (St. Louis, MO, USA). BITC was dissolved in DMSO as a stock for further experiments. All control cultures were added carrier solvent (0.5\% DMSO). Cell culture medium (RPMI-1640), fetal bovine serum (FBS), penicillin-streptomycin, 2',7'-dichlorofluorescein diacetate (DCFH-DA), fluo-3-acetometho-xyester (Fluo-3/AM) and 3,3'-dihexyloxacarbo-cyanine iodide $\left(\mathrm{DiOC}_{6}\right)$ were purchased from Invitrogen (Carlsbad, CA, USA). PhiPhiLux- $\mathrm{G}_{1} \mathrm{D}_{2}$, CaspaLux8- $\mathrm{L}_{1} \mathrm{D}_{2}$ and CaspaLux 9- $\mathrm{M}_{1} \mathrm{D}_{2}$ were purchased from OncoImmunin (Gaithersburg, MD, USA). The following primary antibodies were used: apoptosis-inducing factor (AIF), cytochrome $c$, calpain 1, inositol-requiring enzyme 1 alpha (IRE1 $\alpha$ ), activating transcription factor 6 alpha (ATF6 $\alpha$ ), glucose-regulated protein 78 (GRP78) (from Santa-Cruz Biotechnology, Inc., Dallas, TX, USA); cleaved caspase3, cleaved caspase-9, B-cell lymphoma 2 (BCL2), X-linked inhibitor of apoptosis (XIAP), BH3 interacting domain death agonist (BID), BCL2-associated $X$ protein (BAX), caspase-7 (all from Cell Signaling, St Louis, MO, USA); growth arrest and DNA-damage protein 153 (GADD153), $\beta$-actin (from Sigma Chemical Co., St. Louis, Missouri, USA); and endonuclease G (ENDO G) (Millipore, Temecula, CA, USA), and poly (ADP-ribose) polymerase (PARP) (Abcam, Cambridge, MA, USA).

Cell culture. The NCI-H460 human lung cancer cell line was obtained from the Food Industry Research and Development Institute (Hsinchu, Taiwan, ROC) and was maintained in RPMI1640 medium supplemented with $10 \%$ FBS, $0.1 \mathrm{mg} / \mathrm{ml}$ streptomycin, and 100 units $/ \mathrm{ml}$ penicillin. Cells were cultured at $37^{\circ} \mathrm{C}$ in an atmosphere of $5 \% \mathrm{CO}_{2}(18)$.

Establishment of gefitinib-resistant NCI-H460 human lung cancer cells. Gefitinib-resistant NCI-H460 human lung cancer cells were obtained via their exposure to increasing concentrations of gefitinib. Briefly, NCI-H460 cells were initially cultured in RPMI-1640 medium containing gefitinib at half the concentration causing $50 \%$ growth inhibition $\left(\mathrm{IC}_{50}\right)$ (19). Cells were sub-cultured in RPMI-1640 medium with the concentration of gefitinib increased by $25 \%$ every 2 weeks for 2-3 months. The resultant cells that grew exponentially under a high concentration of gefitinib were recognized to be getifinib-resistant NCI-H460 human lung cancer cells (designated NCI-H460/G). The sensitive parental cells were used to compare the surviving daughter cells using combination cell viability assay by flow cytometry. The cell lines were exposed to a range of drug concentrations and total cell viability was measured $(20,21)$.

Cell morphological changes and viability assay. NCI-H460 cells $\left(1 \times 10^{5}\right.$ cells/well $)$ were incubated with BITC $(0,5,10,15,20,25$ and $30 \mu \mathrm{M})$ or gefitinib $(40 \mu \mathrm{M})$ for $48 \mathrm{~h}$. NCI-H460/G cells $\left(1 \times 10^{5}\right.$ cells/well) were incubated with $\operatorname{BITC}(0,15,20,25$ and $30 \mu \mathrm{M})$ for $48 \mathrm{~h}$. After incubation, cells were examined and photographed under phase-contrast microscopy and were then collected and stained with PI $(5 \mu \mathrm{g} / \mathrm{ml})$ for total viable cell number by flow cytometry (BectonDickinson, San Jose, CA, USA) as previously described (18).

Apoptotic cell death assay. NCI-H460 and NCI-H460/G cells $\left(1 \times 10^{5}\right.$ cells/well) were incubated without agent or with $40 \mu \mathrm{M}$ of gefitinib for $48 \mathrm{~h}$ or with BITC $(25 \mu \mathrm{M})$ for $6,12,24$ and $48 \mathrm{~h}$. Cells were collected and were double-stained with annexin V/PI for analysis of total apoptotic cell death by flow cytometry as previously described (18).

DAPI assay. NCI-H460 and NCI-H460/G cells $\left(1 \times 10^{5}\right.$ cells/well $)$ were incubated with or without $40 \mu \mathrm{M}$ of gefitinib for $48 \mathrm{~h}$ or with BITC $(25 \mu \mathrm{M})$ for $6,12,24$ and $48 \mathrm{~h}$. Cells were collected and fixed in $3 \%$ paraformaldehyde in PBS for $20 \mathrm{~min}$ at room temperature. Cells were then stained with DAPI solution $(2 \mu \mathrm{g} / \mathrm{ml})$ in order to examine DNA condensation, and were photographed using a fluorescence microscope as previously described (22).

Measurement of reactive oxygen species (ROS), intracellular $\mathrm{Ca}^{2+}$ and mitochondrial membrane potential $\left(\Psi_{m}\right)$. NCI-H460 and NCI$\mathrm{H} 460 / \mathrm{G}$ cells $\left(1 \times 10^{5}\right.$ cells/well $)$ were incubated with gefitinib $(40 \mu \mathrm{M})$ or BITC $(25 \mu \mathrm{M})$ for $6,12,24$ and $48 \mathrm{~h}$. After incubation, cells were harvested and were re-suspended in $500 \mu 1$ of DCFH-DA $(10 \mu \mathrm{M}), 500 \mu \mathrm{l}$ of Fluo-3/AM $(2.5 \mu \mathrm{g} / \mathrm{ml})$, and $500 \mu \mathrm{l}$ of $\mathrm{DiOC}_{6}$ (4 $\mu \mathrm{mol} / \mathrm{l})$ for $30 \mathrm{~min}$ to measure the changes of $\operatorname{ROS}\left(\mathrm{H}_{2} \mathrm{O}_{2}\right)$, intracellular $\mathrm{Ca}^{2+}$, and $\Delta \Psi_{\mathrm{m}}$, respectively. All samples were analyzed by flow cytometry as previously described $(23,24)$. All samples were assayed in triplicate.

Measurement of caspase-3, -8 and -9 activities. NCI-H460 and NCI$\mathrm{H} 460 / \mathrm{G}$ cells $\left(1 \times 10^{5}\right.$ cells/well) were incubated with gefitinib $(40 \mu \mathrm{M})$ or BITC $(25 \mu \mathrm{M})$ for $6,12,24$ and $48 \mathrm{~h}$. Cells were collected and were re-suspended in $25 \mu \mathrm{l}$ of $20 \mu \mathrm{M}$ substrate solutions (CaspaLux 8- $\mathrm{L}_{1} \mathrm{D}_{2}$, CaspaLux-9- $-M_{1} D_{2}$ and PhiPhiLux- $G_{1} D_{2}$ ) for caspase-8, -9 and -3 , respectively. The activity of the individual caspase was measured by using flow cytometry as previously described $(12,18)$. 
A

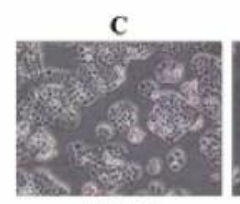

$15 \mu \mathrm{M}$

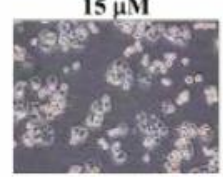

.
G

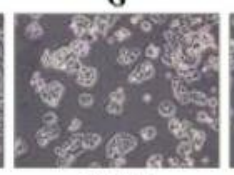

$20 \mu \mathrm{M}$

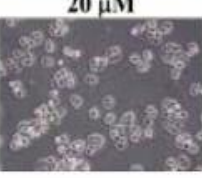

$5 \mu \mathbf{M}$

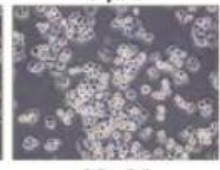

$25 \mu \mathrm{M}$

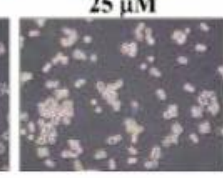

$10 \mu \mathrm{M}$

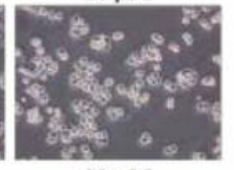

$\mathbf{3 0} \mu \mathrm{M}$

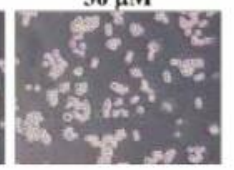

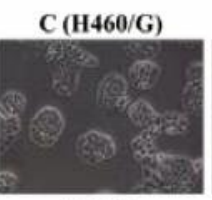

$25 \mu \mathrm{M}$

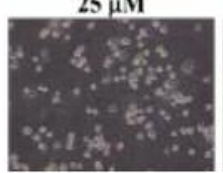

$15 \mu \mathrm{M}$

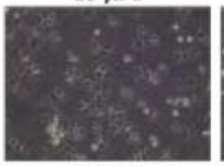

$30 \mu \mathrm{M}$

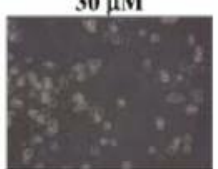

$20 \mu \mathrm{M}$
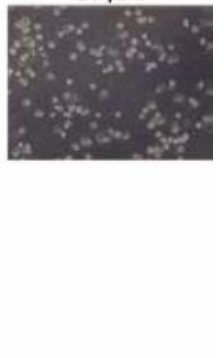

\section{B}
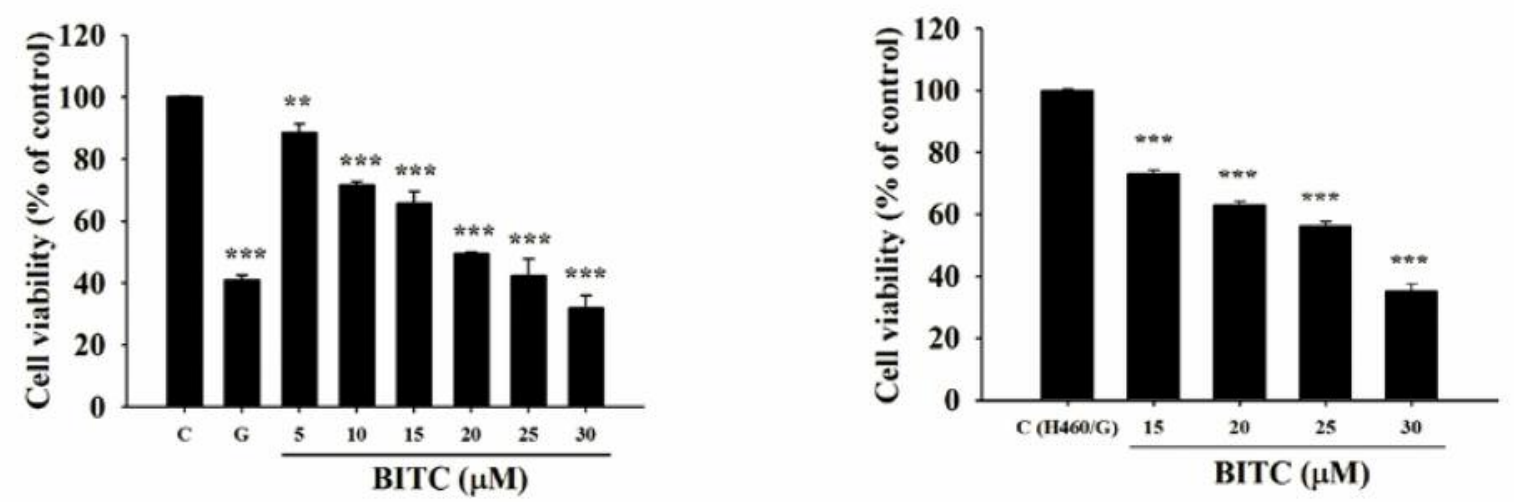

Figure 1. Gefitinib and benzyl isothiocyanate (BITC) induced cell morphological changes (A) and reduced the cell viability (B) of NCI-H460 and $N C I-H 460 / G$ cells. Cells $\left(1 \times 10^{5}\right.$ cells/well $)$ were treated with gefitinib $(G ; 40 \mu M)$ and different concentrations of BITC for 48 h. Cells were then examined and photographed for morphological changes and were harvested for total viable cell viability as described in the Materials and Methods section. Significantly different from the control $(C)$ at $* * p<0.01$ and $* * * p<0.001$ as analyzed by the Dunnett's test.

Protein extraction and western blotting analysis. NCI-H460 and NCI-H460/G cells $\left(1 \times 10^{6}\right.$ cells/dish) were incubated with gefitinib $(40 \mu \mathrm{M})$ or BITC $(25 \mu \mathrm{M})$ for $6,12,24$ and $48 \mathrm{~h}$. Cells were collected and gently re-suspended in lysis buffer for sonication and centrifuged as previously described $(25,26)$ The total protein was determined by Bio-Rad protein assay kit (Bio-Rad, Hercules, CA, USA) from the cell supernatant and with bovine serum albumin (BSA) as the standard. Each sample (protein) was electrophoresed on sodium dodecyl sulfate-polyacrylamide gel electrophoresis and then electrotransferred onto polyvinylidene fluoride membrane (Millipore, Bedford, MA, USA), washed and incubated with primary antibodies AIF, BCL2, XIAP, BID, BAX, ENDO G, PARP, GADD153, GRP78, IRE1 $\alpha$, ATF6 $\alpha$, and $\beta$-actin. The membranes were washed and incubated with horseradish peroxidase-conjugated secondary antibodies $(1: 10,000)$. Immunoreactivity of protein was visualized and detected by Immobilon ${ }^{\mathrm{TM}}$ Western Chemiluminescent HRP Substrate (Millipore) $(25,26)$.

Statistical analysis. Three separate experiments were performed and all data were expressed as mean \pm SD. Differences between groups were analyzed by one-way analysis of variance and Dunnett test for multiple comparisons (SigmaPlot for Windows version 12.0; Systat Software, Inc., San Jose, CA, USA). Differences with a $p$-value of less than 0.05 were considered an indications of statistical significance.

\section{Results}

BITC induced cell morphological changes and reduced viability of NCI-H460 and NCI-H460/G cells. Gefitinib at $40 \mu \mathrm{M}$ reduced viable NCI-H460 cells by more than $50 \%$ (Figure 1A). When NCI-H460 and NCI-H460/G cells were treated with different concentrations of BITC for $48 \mathrm{~h}$, BITC significantly induced cell morphological changes (Figure 1A) and reduced the total viable number of NCIH460 and NCI-H460/G cells in a dose-dependent manner (Figure 1B).

BITC induced apoptotic cell death in NCI-H460 and NCIH460/G cells. NCI-H460 and NCI-H460/G cells were treated with gefitinib $(40 \mu \mathrm{M})$ or BITC $(25 \mu \mathrm{M})$ for different time periods and apoptotic cell death was determined. The results presented in Figure 2A indicate that BITC induced apoptotic cell death in both NCI-H460 and NCI-H460/G cells in a time-dependent manner. However, BITC induced a higher percentage of apoptotic death in NCI-H460/G cells than in NCI-H460 cells (Figure 2B). 
A
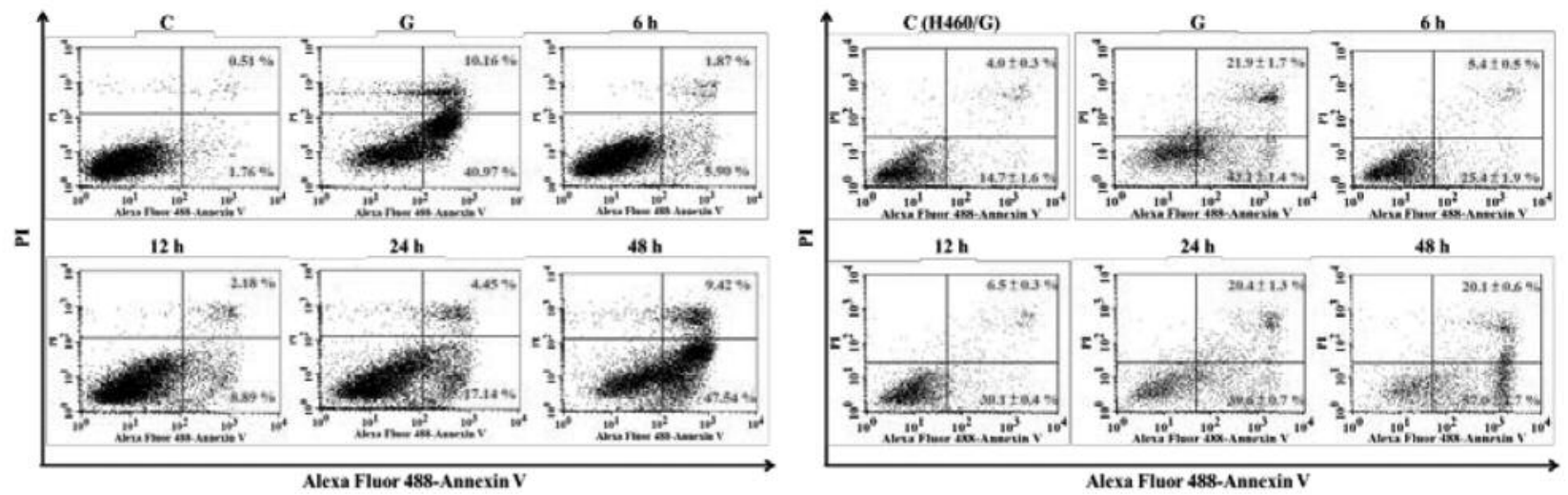

B
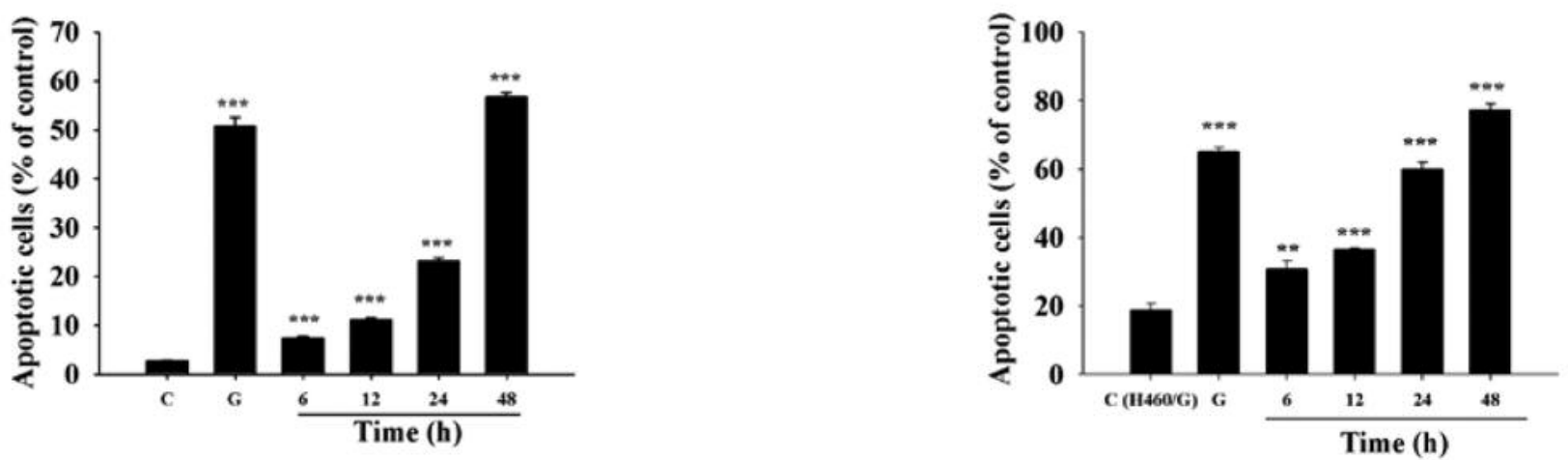

Figure 2. Benzyl isothiocyanate (BITC) induced apoptotic cell death in NCI-H460 and NCI-H460/G cells. Cells were treated with gefitinib (G; $40 \mu \mathrm{M})$ or BITC $(25 \mu \mathrm{M})$ for 6, 12, 24 and $48 \mathrm{~h}$ and were measured for apoptotic cell death using annexin V/propidium iodide (PI) double staining as described in Materials and Methods section. A: Representative cytograms. B: Quantitative presentation of data. Significantly different from the control (C) at **p<0.01 and $* * * p<0.001$ as analyzed by Dunnett test.

BITC induced chromatin condensation in NCI-H460 and NCI-H460/G cells. After NCI-H460 and NCI-H460/G cells were exposed to gefitinib $(40 \mu \mathrm{M})$ or BITC $(25 \mu \mathrm{M})$ for 6 , 12, 24 and $48 \mathrm{~h}$, cells were stained with DAPI and photographed under fluorescence microscopy. The brighter fluorescence in NCI-H460 cells than that of NCI-H460/G cells after $48 \mathrm{~h}$ treatment with BITC $(25 \mu \mathrm{M})$ was obvious (Figure 3). The bright fluorescence reflects the presence of nicked DNA and chromatin condensation.

BITC induced intracellular $\mathrm{Ca}^{2+}$ production, and reduced ROS production and $\Psi_{m}$ in NCI-H460 and NCI-H460/G cells. Cells were treated with gefitinib $(40 \mu \mathrm{M})$ or BITC $(25 \mu \mathrm{M})$ for $6,12,24$ and $48 \mathrm{~h}$, and harvested for measuring ROS, $\mathrm{Ca}^{2+}$ and $\Psi_{m}$ using flow cytometry. As shown in Figure 4A, in NCI-H460 cells, gefitinib did not significantly affect ROS production. However, 6-24 h BITC treatment increased ROS production but $48 \mathrm{~h}$ treatment did not significantly affect ROS production. Similarly, while 6-12 h treatment of NCI-H460/G cells led to increased ROS production, 24-48 h treatment did not significantly affect ROS production (Figure 4A). Figure 4B indicates that gefitinib significantly increased $\mathrm{Ca}^{2+}$ release in parental cells but had no significant effect on $\mathrm{Ca}^{2+}$ release from resistant cells. BITC increased $\mathrm{Ca}^{2+}$ release at $12-48 \mathrm{~h}$ treatment in both NCI-H460 and NCI-H460/G cells, however, at $48 \mathrm{~h}$ treatment, $\mathrm{Ca}^{2+}$ production was lower than that at $24 \mathrm{~h}$ treatment in NCI-H460/G cells. Gefitinib significantly reduced $\Psi_{m}$ in NCI-H460 cells but had no effect on NCI$\mathrm{H} 460 / \mathrm{G}$ cells. BITC also reduced $\Psi_{m}$ at $6-48 \mathrm{~h}$ and $24-48 \mathrm{~h}$ treatment in NCI-H460 and NCI-H460/G cells, respectively (Figure 4C). 


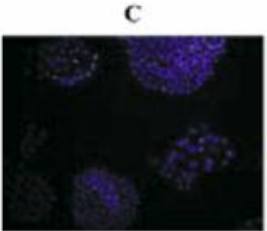

$12 \mathrm{~h}$

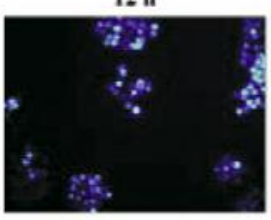

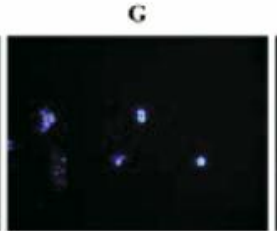

$24 \mathrm{~h}$

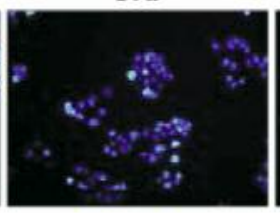

$6 \mathrm{~h}$

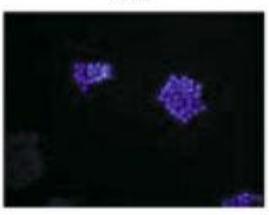

$48 \mathrm{~h}$

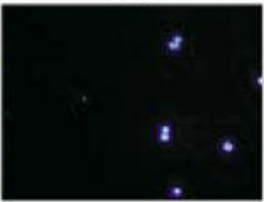

C (H460/G)

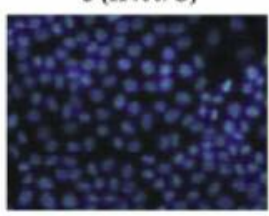

$12 \mathrm{~h}$

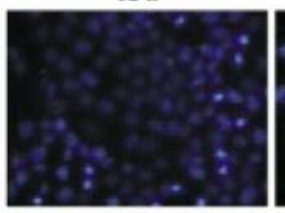

G

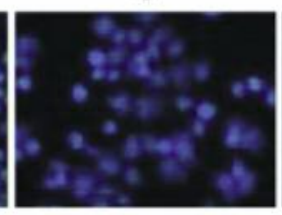

$24 \mathrm{~h}$

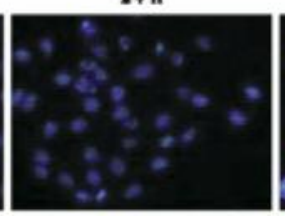

$6 \mathrm{~h}$

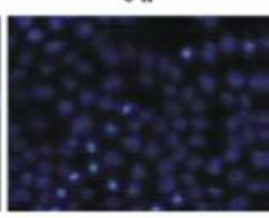

$48 \mathrm{~h}$

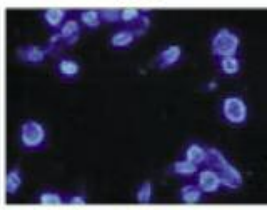

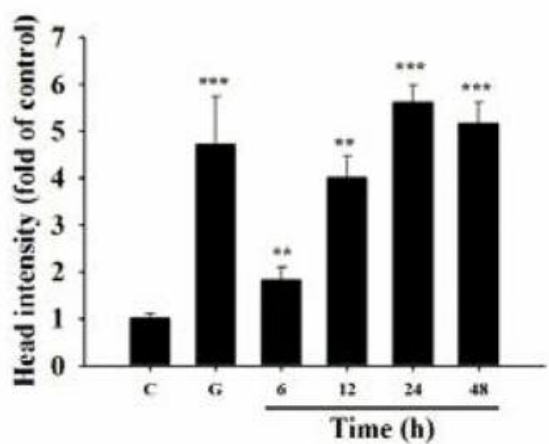

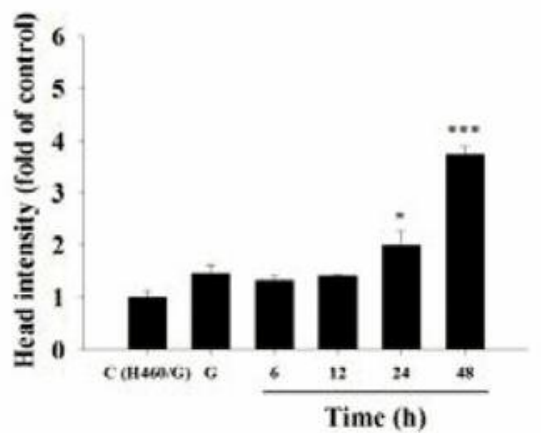

Figure 3. Benzyl isothiocyanate (BITC) induced chromatin condensation in NCI-H460 and NCI-H460/G cells. Cells were treated with gefitinib (G; $40 \mu \mathrm{M})$ or BITC (25 $\mu \mathrm{M})$ for 6, 12, 24 and $48 \mathrm{~h}$ and were stained with 4',6-diamidino-2-phenylindole (DAPI) and photographed using fluorescence microscopy (A) and quantified (B) as described in the Materials and Methods section. Significantly different from the control $(C)$ at $* p<0.05$, $* * p<0.01$ and $* * * p<0.001$ as analyzed by Dunnett test.

BITC induced caspase-3, -8 and -9 activities in NCI-H46O and NCI-H460/G cells. Cells were treated with gefitinib (40 $\mu \mathrm{M})$ or BITC $(25 \mu \mathrm{M})$ for $6,12,24$ and $48 \mathrm{~h}$, and the activities of caspase-3, -8 and -9 were measured using flow cytometry. The results indicated that gefitinib significantly increased caspase-3, -8 and -9 activities in NCI-H460 cells, but not in the NCI-H460/G cells (Figure 5). BITC significantly increased the activity of caspase-3 (Figure 5A) and caspase- 8 (Figure 5B) at $48 \mathrm{~h}$ treatment in NCI-H460 cells and at $12-48 \mathrm{~h}$ treatment in NCI-H460/G cells, but at 6 $\mathrm{h}$ reduced caspase- 3 and -8 activities in NCI-H460/G cells (Figure 5A and B). Results also showed that BITC increased caspase- 9 activity at $24-48 \mathrm{~h}$ treatment in NCI-H460 cells but only at $48 \mathrm{~h}$ in NCI-H460/G cells (Figure 5C).

BITC altered expression of apoptosis-associated proteins in NCI-H460 and NCI-H460/G cells. In order to ascertain the molecular mechanisms of BITC-induced apoptotic cell death in NCI-H460 and NCI-H460/G cells, protein expression of BITC-treated cells was examined by western blotting. The results indicate that BITC increased AIF, cleaved caspase-3, and caspase-9 (Figure 6A), XIAP and cytochrome $c$ (Figure 6B), BAX, ENDO G and PARP (86 kDa) (Figure 6C), GADD153, calpain 1, caspase-7 and ATF6 $\alpha$ (Figure 6D), but reduced the expression of BCL2 (Figure 6B), BID (Figure 6C), GRP78 and IRE1 $\alpha$ (Figure 6D) in NCI-H460 cells. In NCI-H460/G cells, BITC increased cleaved caspase-3 and -9 (Figure 6A), cytochrome $c$ (Figure 6B), BAX, ENDO G and PARP (86 kDa) (Figure 6C), GADD153, caspase-7 and ATF6 $\alpha$ (Figure 6D), but reduced AIF (Figure 6A), BID (Figure 6C), calpain 1, GRP78 and IRE1 $\alpha$ (Figure 6D).

\section{Discussion}

It is well documented that gefitinib has been used clinically for patients with lung cancer and significantly suppresses cancer cell proliferation and total cell viability. Some patients with lung cancer who were treated with gefitinib became gefitinib-resistant $(27,28)$ that led to treatment failure. Currently, many studies are focused on finding natural compounds for treating lung cancer to increase efficiency of treatment. BITC can inhibit the growth of human glioma U87MG cells outside the body via causing 
A
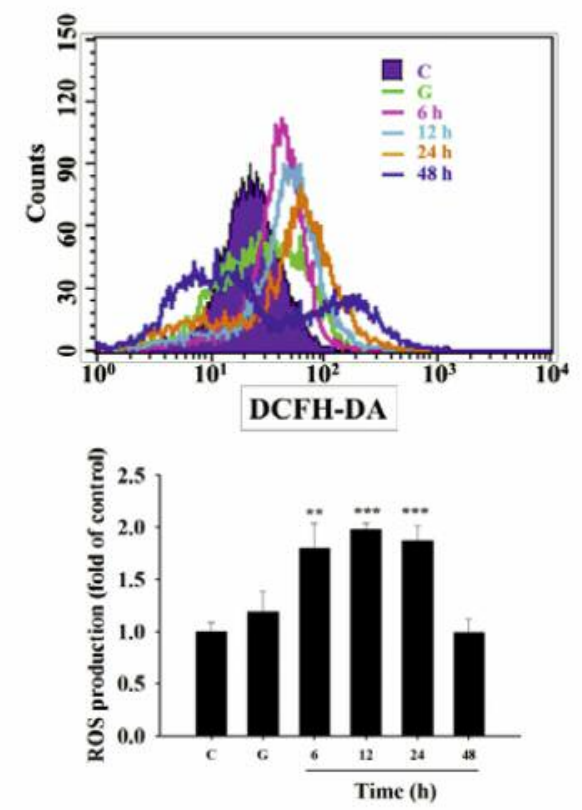

B
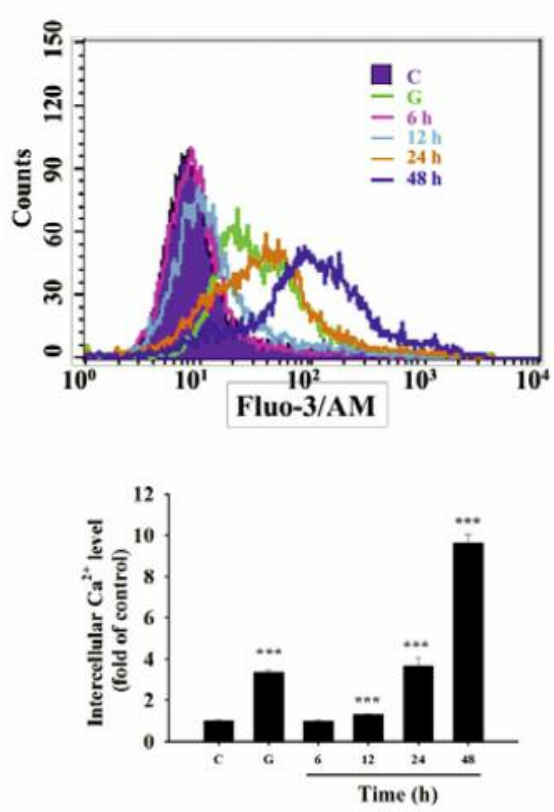
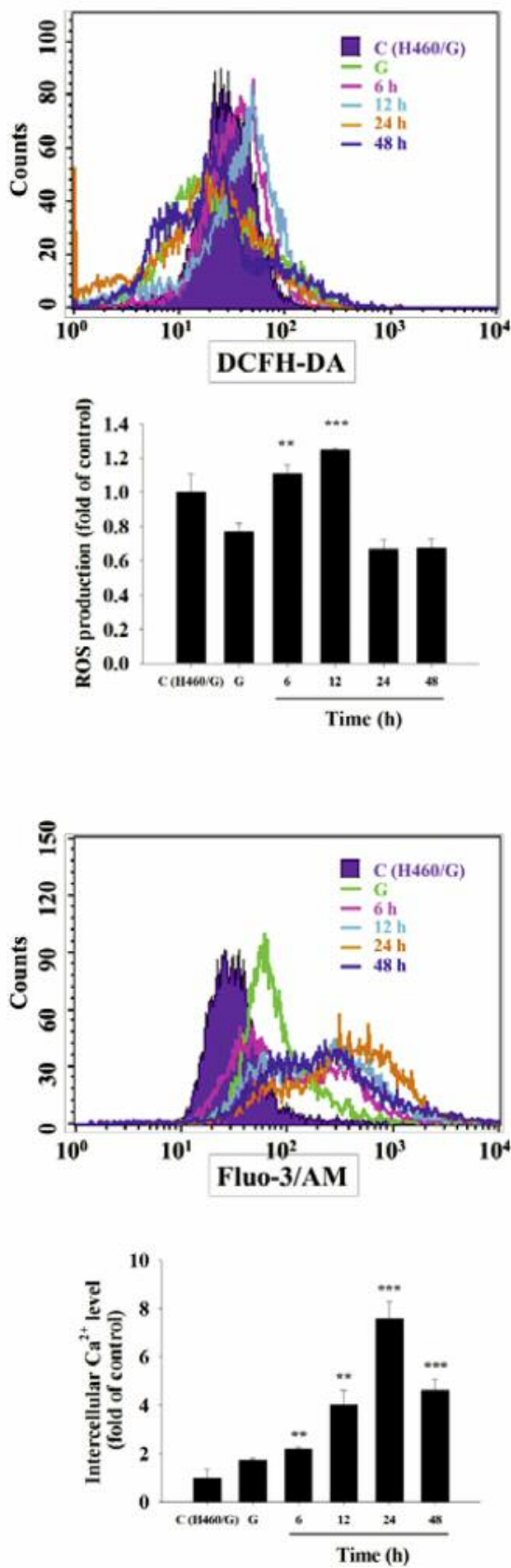

Figure 4. Continued

total cell viability of $\mathrm{NCI}-\mathrm{H} 460 / \mathrm{G}$ cells and then further investigated the possible molecular mechanism in vitro. We found that in NCI-H460/G cells, BITC i) significantly reduced the total viable cell number, and induced apoptotic cell death; ii) induced chromatin condensation; iii) increased production of ROS and $\mathrm{Ca}^{2+}$, reduced $\Psi_{m}$, and increased caspase-3, -8 and -9 activities; iv) increased expression of 

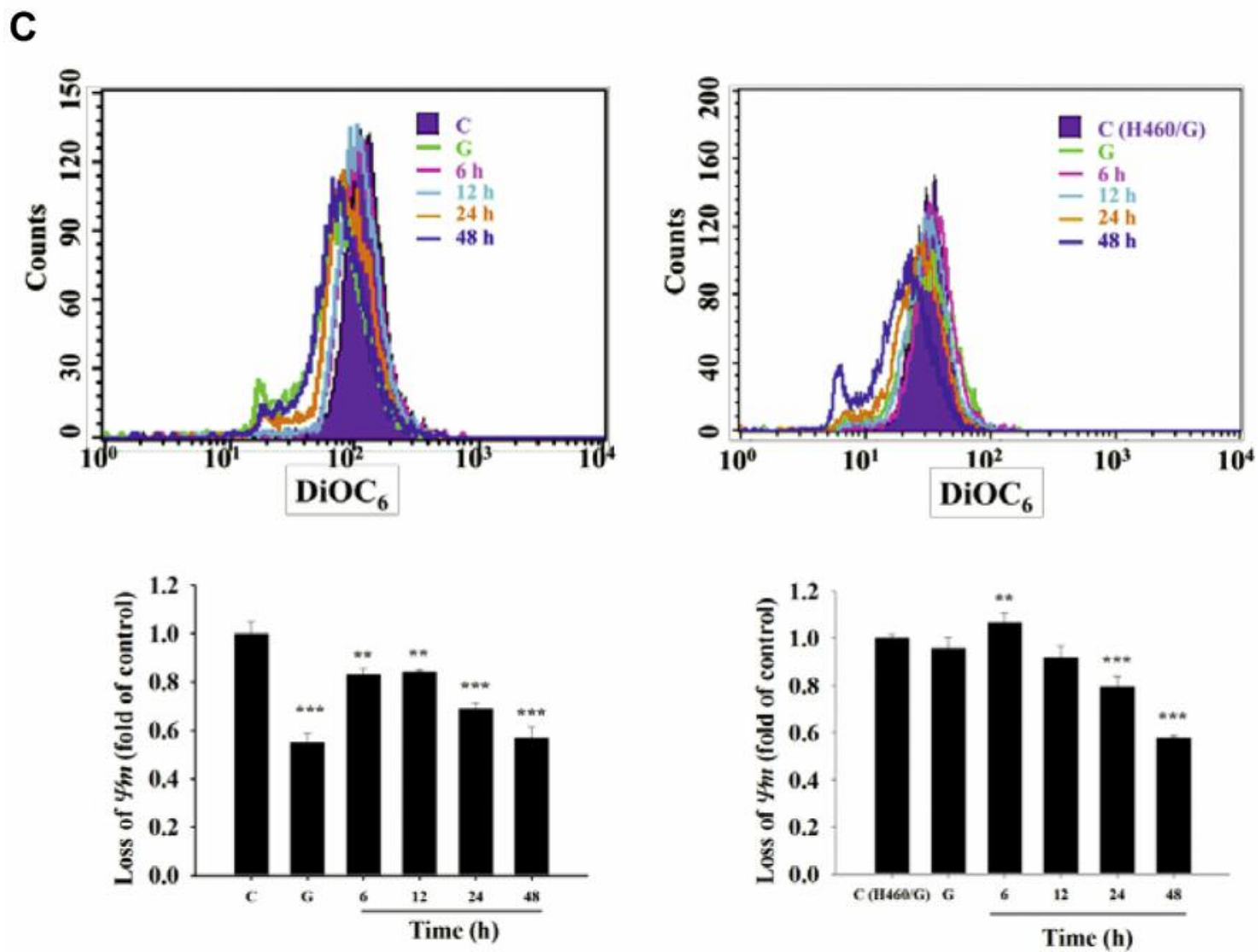

Figure 4. Benzyl isothiocyanate (BITC) affected reactive oxygen species (ROS) (A), intracellular $C a^{2+}(B)$ and mitochondrial membrane potential $\left(\Psi_{m}\right)(C)$ in NCI-H460 and NCI-H460/G cells. Cells $\left(1 \times 10^{5}\right.$ cells/well $)$ were incubated with gefitinib $(G ; 40 \mu M)$ or BITC $(25 \mu M)$ for 6, 12,24 and $48 \mathrm{~h}$ and $\mathrm{ROS}, \mathrm{Ca}^{2+}$ and $\Delta \Psi_{m}$ were then measured as described in the Materials and Methods section. Significantly different from the control (C) at $* * p<0.01$ and $* * * p<0.001$ as analyzed by Dunnett test.

apoptotic-associated proteins such as cleaved caspase- 3 and -9 . We also used normal NCI-H460 as positive control throughout the whole study.

Firstly, we generated gefitinib-resistant NCI-H460 cells for examining the effects of BITC on survival and found similar results as reported by another group showing that BITC affects human lung cancer and gefitinib-resistant lung cancer cell lines (17). We further found that BITC induced apoptotic cell death in both cell lines by DAPI staining and annexin V/PI double staining, which are accepted methods for measuring apoptotic cell death. Induction of cancer cell apoptosis is one of the best strategies for anticancer drug therapy $(34,35)$. In the present study, we found that BITC increased ROS and $\mathrm{Ca}^{2+}$ but reduced $\Psi_{m}$ in both NCI-H460 and NCI-H460/G cells. It is well known that ROS is involved in cancer cell death and ROS increases the induction of autophagy when cells are under starvation or stress conditions (36). The $\mathrm{Ca}^{2+}$ uptake into the mitochondrial matrix is related to several cellular function (37). The endoplasmic reticulum
(ER) stress apoptotic pathway, which includes $\mathrm{ROS}$ and $\mathrm{Ca}^{2+}$ production following the activation of caspase-3, causes apoptosis (38). Thus, we found that BITC treatment of NCIH460/G cells induced apoptotic cell death, involving ROS through ER stress.

The mitochondria are associated with the stimulation of apoptosis in the intrinsic signaling pathway $(39,40)$. Based on the results from western blotting (Figure 6), BITC increased AIF (Figure 6A) and cytochrome $c$ (Figure 6B) in NCI-H460 cells. These results also further confirm that BITC reduced $\Psi_{m}$ (Figure 4C). BITC increased the expressions of cleaved caspase-9 and -3 (Figure 6A); proapoptotic protein BAX (Figure 6C); caspase-7 and ATF6 $\alpha$ (Figure 6D) in both cell types. BCL2 family proteins are associated with mitochondria-dependent pathway and death receptor dependent pathway $(38,41)$. Furthermore, the BCL2 family includes pro-apoptotic proteins such as BAX and antiapoptotic proteins such as BCL2 and both proteins affect the function of mitochondria (42). 
A
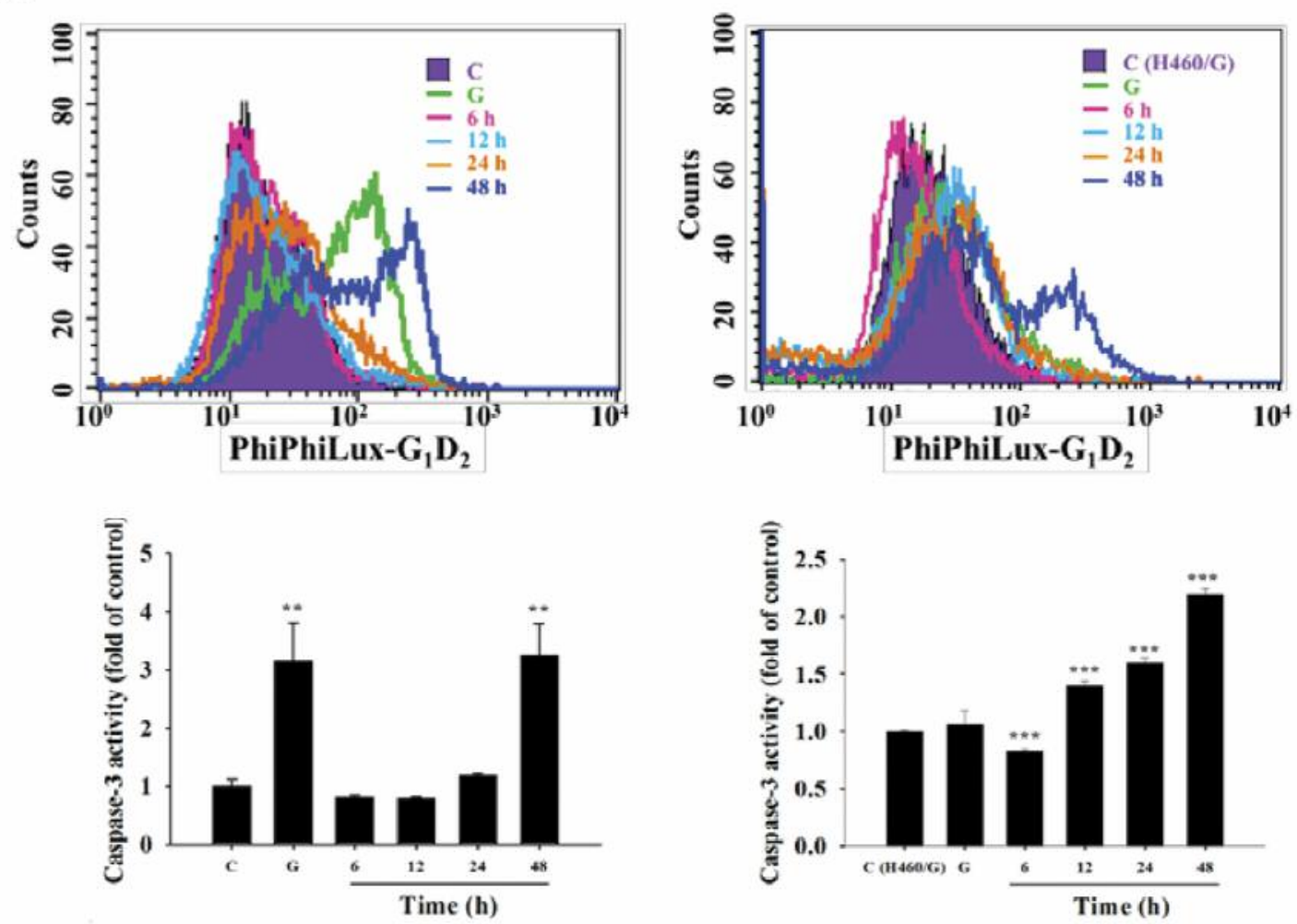

B
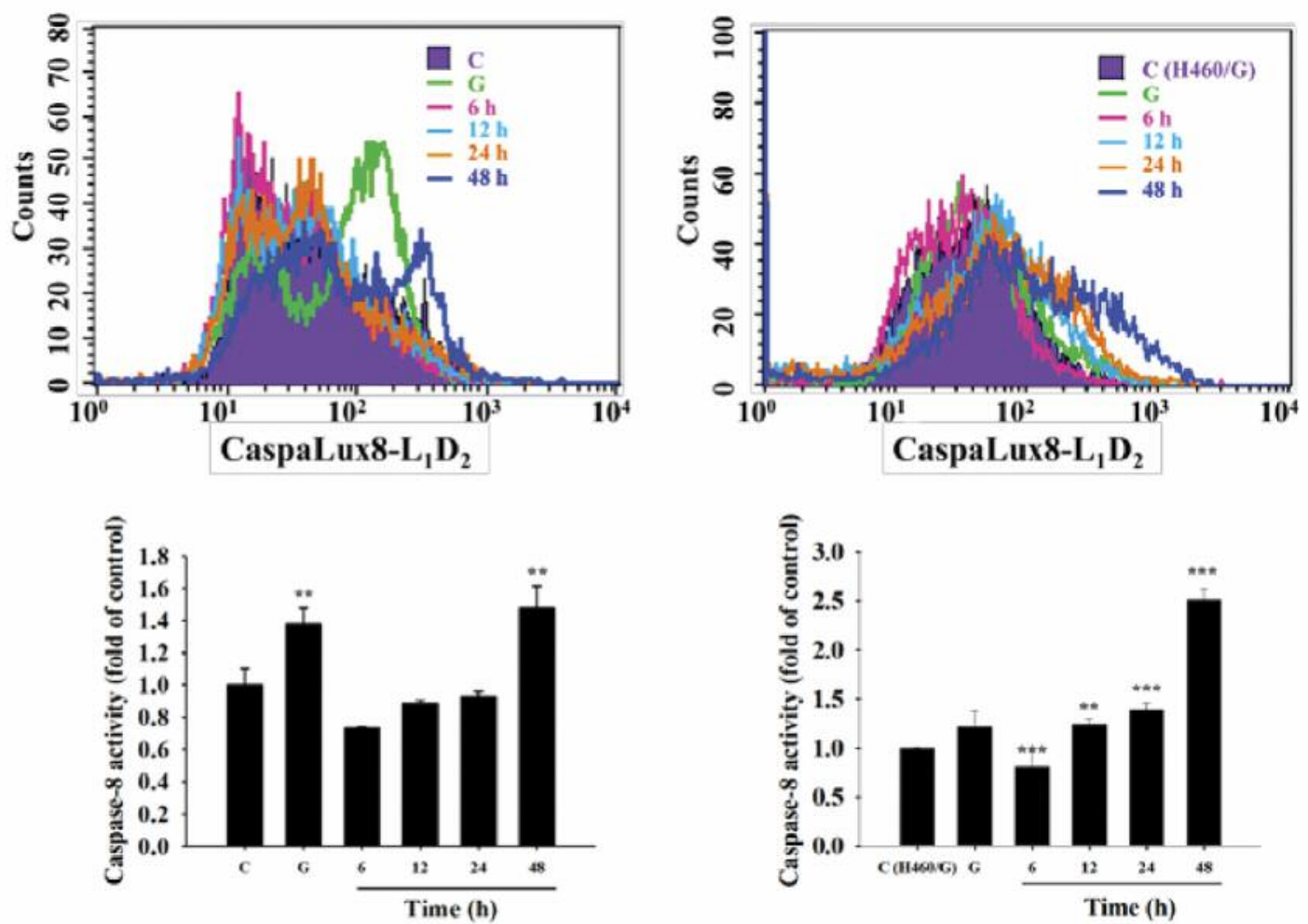

Figure 5. Continued 

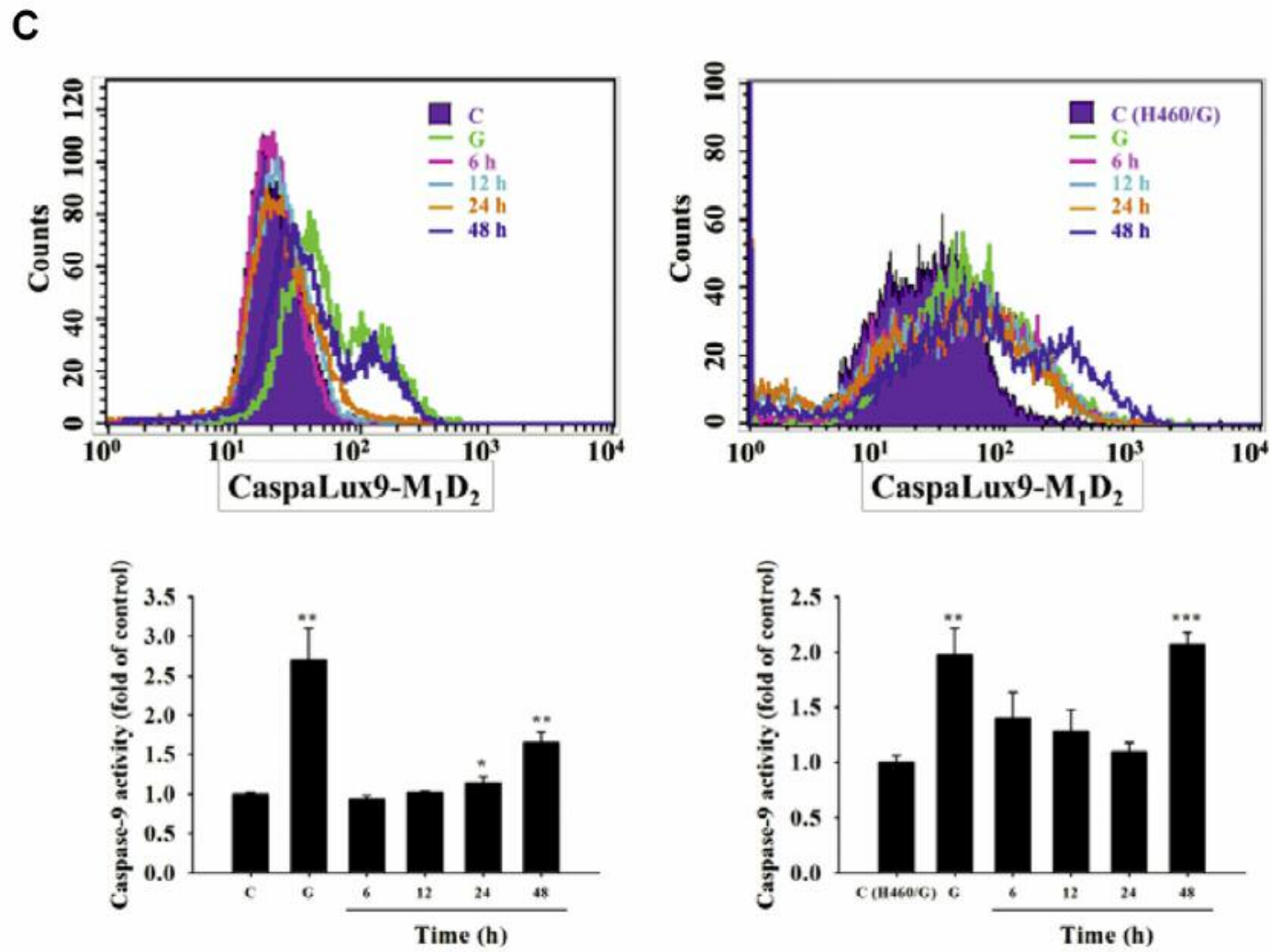

Figure 5. Benzyl isothiocyanate (BITC) induced caspase activity in NCI-H460 and NCI-H460/G cells. Cells were treated with gefitinib (G; $40 \mu M)$ or BITC $(25 \mu M)$ for $6,12,24$ and $48 \mathrm{~h}$ and caspase-3 $(A),-8(B)$ and $-9(C)$ activities were measured using flow cytometric assays as described in the Materials and Methods section. Significantly different from the control $(C)$ at $* p<0.05$, **p<0.01, and ***p<0.001 as analyzed by the Dunnett's test.

Results from Figure 4A indicated that BITC increased ROS production at 6-24 h treatment in NCI-H460 cells and at 6-12 $\mathrm{h}$ treatment in NCI-H460/G cells. Furthermore, expression of markers of ER stress, such as GADD153, was increased at 6$24 \mathrm{~h}$ treatment of NCI-H460/G cells but only at $48 \mathrm{~h}$ treatment was increased in NCI-H460 cells (Figure 6D). ATF6 $\alpha$ was increased in both NCI-H460 and NCI-H460/G cells after treatment with BITC (Figure 6D). Thus, we may suggest that BITC-induced apoptotic cell death may involve ER stress. Caspase-7 activation increased in both cell types after treatment with BITC (Figure 6D). The ER is a central intracellular organelle in the secretory pathway and exerts a cytoprotective role but when ER stress becomes too severe or prolonged, it may lead to a toxic signal which causes tumor cell death (43, 44). Based on these observations, BITC induced apoptotic cell death in NCI-H460 and NCI-H460/G cells in vitro may occur through ER stress and mitochondria-dependent pathways.

\section{Conflict of Interest}

The Authors declare that there are no conflicts of interest in regard to this study.

\section{Acknowledgements}

This work was supported by the Ministry of Science and Technology, Taipei, Taiwan [grant numbers MOST 104-2320-B039-039-]. Experiments and data analysis were performed in part through the use of the Medical Research Core Facilities Center, Office of Research \& Development at China medical University, Taichung, Taiwan.

\section{References}

1 Jemal A, Bray F, Center MM, Ferlay J, Ward E and Forman D: Global cancer statistics. CA Cancer J Clin 61: 69-90, 2011.

2 Hall MD, Handley MD and Gottesman MM: Is resistance useless? Multidrug resistance and collateral sensitivity. Trends Pharmacol Sci 30: 546-556, 2009.

3 Fukuoka M, Yano S, Giaccone G, Tamura T, Nakagawa K, Douillard JY, Nishiwaki Y, Vansteenkiste J, Kudoh S, Rischin D, Eek R, Horai T, Noda K, Takata I, Smit E, Averbuch S, Macleod A, Feyereislova A, Dong RP and Baselga J: Multiinstitutional randomized phase II trial of gefitinib for previously treated patients with advanced non-small-cell lung cancer (The IDEAL 1 Trial) [corrected]. J Clin Oncol 21: 2237-2246, 2003. 
A A AIF

Cleaved caspase-3

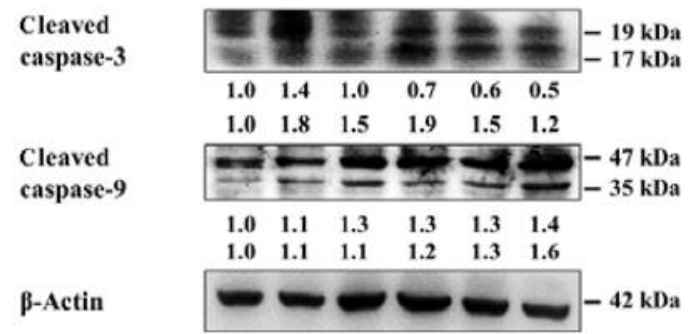

B

BCL2

XIAP

Cytochrome c

$\beta$-Actin

C

BID

BAX

ENDO G

PARP

$\beta$-Actin

D

GADD153

calpain 1

caspase-7

GRP78

IRE1 $\alpha$

ATF6e

$\beta$-Actin

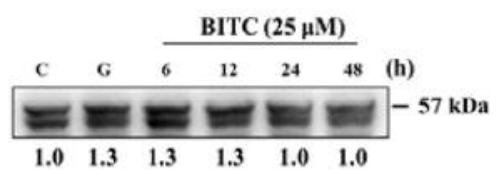

$\begin{array}{llllll}1.0 & 1.3 & 1.3 & 1.3 & 1.0 & 1.0\end{array}$

BITC $(25 \mu \mathrm{M})$
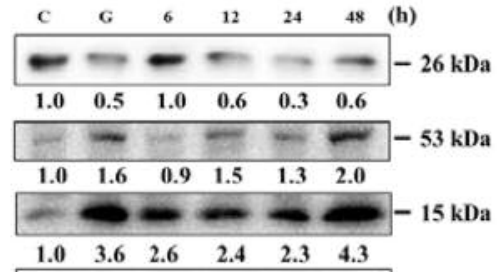

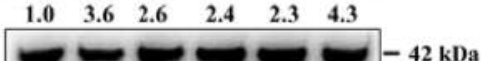

BITC $(25 \mu \mathrm{M})$

$\begin{array}{lllllll}\text { C } & \text { G } & 6 & 12 & 24 & 48 & \text { (h) }\end{array}$

$-\infty-\infty-21 \mathrm{kDa}$ $\begin{array}{llllll}1.0 & 0.8 & 0.5 & 0.7 & 0.6 & 0.6\end{array}$

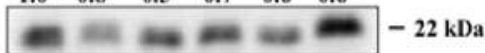

$\begin{array}{llllll}1.0 & 0.5 & 0.6 & 0.6 & 0.5 & 1.2\end{array}$

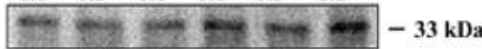

$\begin{array}{llllll}1.0 & 1.1 & 0.8 & 1.1 & 1.0 & 1.5\end{array}$

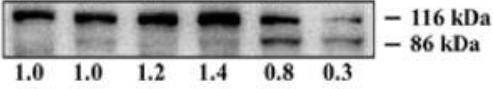

$\begin{array}{llllll}1.0 & 1.5 & 1.3 & 1.5 & 2.0 & 1.8\end{array}$

$-2-2-42 \mathrm{kDa}$

$\operatorname{BITC}(25 \mu \mathrm{M})$

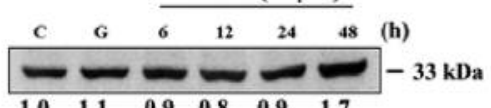

$\begin{array}{llllll}1.0 & 1.1 & 0.9 & 0.8 & 0.9 & 1.7\end{array}$

$-\infty-80 \mathrm{kDa}$

$\begin{array}{llllll}1.0 & 0.8 & 0.8 & 1.0 & 0.6 & 1.2\end{array}$

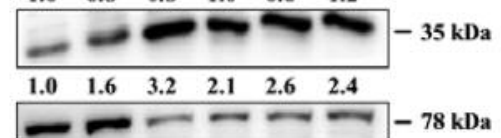

$-\square--78 \mathrm{kDa}$

$\begin{array}{llllll}1.0 & 1.1 & 0.4 & 0.4 & 0.4 & 0.5\end{array}$

एक

$\begin{array}{llllll}1.0 & 1.9 & 1.1 & 0.6 & 0.9 & 0.5\end{array}$

\begin{tabular}{|llllll}
\hline & & & -90 & $\mathrm{kDa}$
\end{tabular}

$\begin{array}{llllll}1.0 & 7.7 & 2.4 & 2.6 & 2.7 & 3.5\end{array}$

$-0000-42 \mathrm{kDa}$
AIF

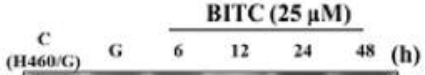

Cleaved

caspase-3

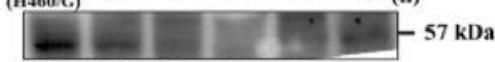

$\begin{array}{llllll}1.0 & 0.6 & 0.5 & 0.3 & 0.4 & 0.6\end{array}$

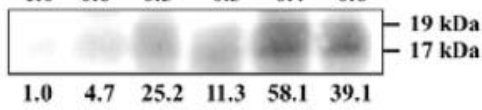

$\begin{array}{llllll}1.0 & 7.9 & 28.8 & 30.8 & 58.0 & 40.6\end{array}$

Cleaved

caspase-9

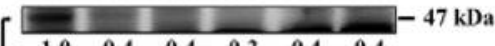

$\begin{array}{llllll}1.0 & 0.4 & 0.4 & 0.3 & 0.4 & 0.4\end{array}$

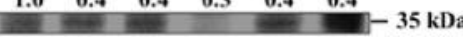

$\begin{array}{llllll}1.0 & 0.8 & 0.9 & 0.2 & 0.9 & 1.4\end{array}$

$\beta$-Actin

$-\longrightarrow-42 \mathrm{kDa}$

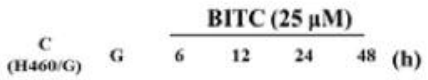

BCL2

XIAP

Cytochrome $\mathrm{c}$

$\longrightarrow-26 \mathrm{kDa}$

$\begin{array}{llllll}1.0 & 1.2 & 1.1 & 1.3 & 1.2 & 0.8\end{array}$

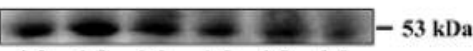

$\begin{array}{llllll}1.0 & 1.5 & 1.6 & 1.6 & 1.8 & 0.8\end{array}$

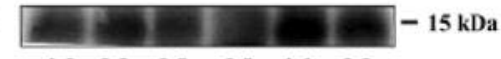

$\begin{array}{llllll}1.0 & 0.9 & 0.8 & 0.8 & 1.1 & 0.9\end{array}$

$\beta$-Actin

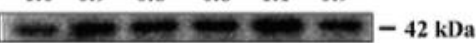

BID

BAX

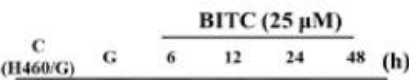

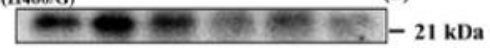

\begin{tabular}{llllll}
1.0 & 1.2 & 1.3 & 1.0 & 1.1 & 0.4 \\
\hline
\end{tabular}

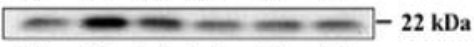

$\begin{array}{llllll}1.0 & 1.6 & 1.4 & 1.4 & 1.3 & 0.7\end{array}$

ENDO G

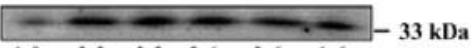

PARP

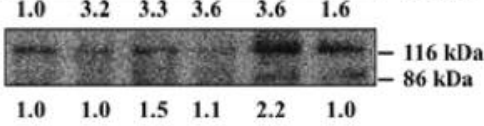

$\begin{array}{llllll}1.0 & 1.0 & 1.5 & 1.1 & 2.2 & 1.0\end{array}$

$\beta$-Actin
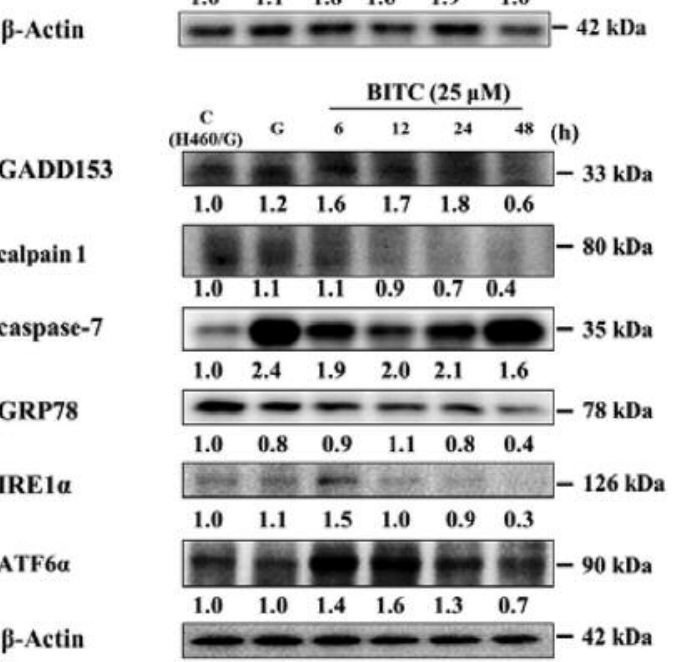

Figure 6. Benzyl isothiocyanate (BITC) altered expression of apoptosis-associated proteins in NCI-H460 and NCI-H460/G cells. Cells were treated with gefitinib $(G ; 40 \mu M)$ or BITC $(25 \mu M)$ for $6,12,24$ and $48 \mathrm{~h}$ and protein expressions were measured by western blotting as described in the Materials and Methods. AIF: Apoptosis-inducing factor; cleaved caspase-3, cleaved caspase-9, BCL2: B-cell lymphoma 2; XIAP: X-linked inhibitor of apoptosis; BID: BH-interacting domain death agonist; BAX: BCL2-associated X protein; ENDO G: endonuclease G; PARP: poly (ADP-ribose) polymerase; GADD153: growth arrest and DNA damage protein 153; GRP78: glucose-regulated protein 78; IRE1 2 : inositol-requiring enzyme 1; calpain 1; caspase-7; ATF6 $\alpha$ : alpha activating transcription factor 6 alpha. 
4 Perez-Soler R, Chachoua A, Hammond LA, Rowinsky EK, Huberman M, Karp D, Rigas J, Clark GM, Santabarbara P and Bonomi P: Determinants of tumor response and survival with erlotinib in patients with non-small-cell lung cancer. J Clin Oncol 22: 3238-3247, 2004.

5 Yang $\mathrm{CH}$, Yu CJ, Shih JY, Chang YC, Hu FC, Tsai MC, Chen KY, Lin ZZ, Huang CJ, Shun CT, Huang CL, Bean J, Cheng AL, Pao W and Yang PC: Specific EGFR mutations predict treatment outcome of stage IIIB/IV patients with chemotherapy-naive nonsmall-cell lung cancer receiving first-line gefitinib monotherapy. J Clin Oncol 26: 2745-2753, 2008.

6 Maemondo M, Inoue A, Kobayashi K, Sugawara S, Oizumi S, Isobe H, Gemma A, Harada M, Yoshizawa H, Kinoshita I, Fujita Y, Okinaga S, Hirano H, Yoshimori K, Harada T, Ogura T, Ando M, Miyazawa H, Tanaka T, Saijo Y, Hagiwara K, Morita S and Nukiwa T: Gefitinib or chemotherapy for non-small-cell lung cancer with mutated EGFR. N Engl J Med 362: 2380-2388, 2010.

7 Jackman D, Pao W, Riely GJ, Engelman JA, Kris MG, Janne PA, Lynch T, Johnson BE and Miller VA: Clinical definition of acquired resistance to epidermal growth factor receptor tyrosine kinase inhibitors in non-small-cell lung cancer. J Clin Oncol 28: 357-360, 2010.

8 Morgillo F, Amendola G, Della Corte CM, Giacomelli C, Botta L, Di Maro S, Messere A, Ciaramella V, Taliani S, Marinelli L, Trincavelli ML, Martini C, Novellino E, Ciardiello F and Cosconati S: Dual MET and SMO negative modulators overcome resistance to EGFR inhibitors in human nonsmall cell lung cancer. J Med Chem 60: 7447-7458, 2017.

9 Xiao D, Powolny AA and Singh SV: Benzyl isothiocyanate targets mitochondrial respiratory chain to trigger reactive oxygen species-dependent apoptosis in human breast cancer cells. J Biol Chem 283: 30151-30163, 2008.

10 Batra S, Sahu RP, Kandala PK and Srivastava SK: Benzyl isothiocyanate-mediated inhibition of histone deacetylase leads to NF-kappaB turnoff in human pancreatic carcinoma cells. Mol Cancer Ther 9: 1596-1608, 2010.

11 Liu KC, Huang YT, Wu PP, Ji BC, Yang JS, Yang JL, Chiu TH, Chueh FS and Chung JG: The roles of AIF and Endo G in the apoptotic effects of benzyl isothiocyanate on DU 145 human prostate cancer cells via the mitochondrial signaling pathway. Int J Oncol 38: 787-796, 2011.

12 Huang SH, Wu LW, Huang AC, Yu CC, Lien JC, Huang YP, Yang JS, Yang JH, Hsiao YP, Wood WG, Yu CS and Chung JG: Benzyl isothiocyanate (BITC) induces $\mathrm{G}_{2} / \mathrm{M}$ phase arrest and apoptosis in human melanoma A375.S2 cells through reactive oxygen species (ROS) and both mitochondria-dependent and death receptor-mediated multiple signaling pathways. J Agric Food Chem 60: 665-675, 2012.

13 Zhou T, Li G, Cao B, Liu L, Cheng Q, Kong H, Shan C, Huang $\mathrm{X}$, Chen $\mathrm{J}$ and Gao N: Downregulation of $M C L-1$ through inhibition of translation contributes to benzyl isothiocyanateinduced cell cycle arrest and apoptosis in human leukemia cells. Cell Death Dis 4: e515, 2013.

14 Tang NY, Chueh FS, Yu CC, Liao CL, Lin JJ, Hsia TC, Wu KC, Liu HC, Lu KW and Chung JG: Benzyl isothiocyanate alters the gene expression with cell cycle regulation and cell death in human brain glioblastoma GBM 8401 cells. Oncol Rep 35: 2089-2096, 2016.

15 Yan H, Zhu Y, Liu B, Wu H, Li Y, Wu X, Zhou Q and Xu K: Mitogen-activated protein kinase mediates the apoptosis of highly metastatic human non-small cell lung cancer cells induced by isothiocyanates. Br J Nutr 106: 1779-1791, 2011.

$16 \mathrm{Kim}$ EJ, Hong JE, Eom SJ, Lee JY and Park JH: Oral administration of benzyl-isothiocyanate inhibits solid tumor growth and lung metastasis of 4T1 murine mammary carcinoma cells in BALB/c mice. Breast Cancer Res Treat 130: 61-71, 2011.

17 Liu BN, Yan HQ, Wu X, Pan ZH, Zhu Y, Meng ZW, Zhou QH and $\mathrm{Xu} \mathrm{K}$ : Apoptosis induced by benzyl isothiocyanate in gefitinib-resistant lung cancer cells is associated with AKT/MAPK pathways and generation of reactive oxygen species. Cell Biochem Biophys 66: 81-92, 2013.

$18 \mathrm{Wu}$ SH, Bau DT, Hsiao YT, Lu KW, Hsia TC, Lien JC, Ko YC, Hsu WH, Yang ST, Huang YP and Chung JG: Bufalin induces apoptosis in vitro and has Antitumor activity against human lung cancer xenografts in vivo. Environ Toxicol 32: 1305-1317, 2017.

19 Huang AC, Yang MD, Hsiao YT, Lin TS, Ma YS, Peng SF, Hsia TC, Cheng YD, Kuo CL and Chung JG: Bufalin inhibits gefitinib resistant NCI-H460 human lung cancer cell migration and invasion in vitro. J Ethnopharmacol 194: 1043-1050, 2016.

20 McDermott M, Eustace AJ, Busschots S, Breen L, Crown J, Clynes M, O'Donovan N and Stordal B: In vitro development of chemotherapy and targeted therapy drug-resistant cancer cell lines: A practical guide with case studies. Front Oncol 4: 40, 2014.

21 Hsia TC, Huang YP, Jiang YW, Chen HY, Cheng ZY, Hsiao YT, Chen CY, Peng SF, Chueh FS, Chou YC and Chung JG: Phenethyl isothiocyanate induces apoptotic cell death through the mitochondria-dependent pathway in gefitinib-resistant NCIH460 human lung cancer cells in vitro. Anticancer Res 38: 21372147, 2018 .

22 Chu YL, Ho CT, Chung JG, Raghu R, Lo YC and Sheen LY: Allicin induces anti-human liver cancer cells through the $p 53$ gene modulating apoptosis and autophagy. J Agric Food Chem 61: 9839-9848, 2013.

23 Lee MR, Lin C, Lu CC, Kuo SC, Tsao JW, Juan YN, Chiu HY, Lee FY, Yang JS and Tsai FJ: YC-1 induces $\mathrm{G}_{0} / \mathrm{G}_{1}$ phase arrest and mitochondria-dependent apoptosis in cisplatin-resistant human oral cancer CAR cells. BioMedicine 7: 12, 2017.

24 Leung YM, Wong KL, Chen SW, Lu DY, Kuo CS, Chen YR, Chen YW and Cheng TH: Down-regulation of voltage-gated $\mathrm{Ca}^{2+}$ channels in $\mathrm{Ca}^{2+}$ store-depleted rat insulinoma RINm5F cells. BioMedicine 3: 130-139, 2013.

25 Huang WW, Chiu YJ, Fan MJ, Lu HF, Yeh HF, Li KH, Chen PY, Chung JG and Yang JS: Kaempferol induced apoptosis via endoplasmic reticulum stress and mitochondria-dependent pathway in human osteosarcoma U-2 OS cells. Mol Nutr Food Res 54: 1585-1595, 2010.

26 Lin Y-J, Ho T-J, Lin T-H, Hsu W-Y, Huang S-M, Liao C-C, Lai C-H, Liu X, Tsang H, Lai C-C and Tsai F-J: p-Coumaric acid regulates exon 12 splicing of the $A T P 7 B$ gene by modulating hnRNP A1 protein expressions. BioMedicine 5: 1-9, 2015.

27 Tan CS, Gilligan D and Pacey S: Treatment approaches for EGFR-inhibitor-resistant patients with non-small-cell lung cancer. Lancet Oncol 16: e447-e459, 2015.

28 Lin Y, Wang X and Jin H: EGFR-TKI resistance in NSCLC patients: mechanisms and strategies. Am J Cancer Res 4: 411435, 2014.

29 Zhu Y, Zhuang JX, Wang Q, Zhang HY and Yang P: Inhibitory effect of benzyl isothiocyanate on proliferation in vitro of human glioma cells. Asian Pac J Cancer Prev 14: 2607-2610, 2013. 
30 Ma YS, Hsiao YT, Lin JJ, Liao CL, Lin CC and Chung JG: Phenethyl isothiocyanate (PEITC) and benzyl isothiocyanate (BITC) inhibit human melanoma A375.S2 cell migration and invasion by affecting MAPK signaling pathway in vitro. Anticancer Res 37: 6223-6234, 2017.

31 Ma YS, Lin JJ, Lin CC, Lien JC, Peng SF, Fan MJ, Hsu FT and Chung JG: Benzyl isothiocyanate inhibits human brain glioblastoma multiforme GBM 8401 cell xenograft tumor in nude mice in vivo. Environ Toxicol, 2018. doi: 10.1002/tox.22581. [Epub ahead of print]

32 Ni WY, Hsiao YP, Hsu SC, Hsueh SC, Chang CH, Ji BC, Yang JS, Lu HF and Chung JG: Oral administration of benzylisothiocyanate inhibits in vivo growth of subcutaneous xenograft tumors of human malignant melanoma A375.S2 cells. In Vivo 27: 623-626, 2013.

33 Shang HS, Shih YL, Lu TJ, Lee CH, Hsueh SC, Chou YC, Lu HF, Liao NC and Chung JG: Benzyl isothiocyanate (BITC) induces apoptosis of GBM 8401 human brain glioblastoma multiforms cells via activation of caspase-8/BID and the reactive oxygen species-dependent mitochondrial pathway. Environ Toxicol 31: 1751-1760, 2016.

34 Lee CH, Shih YL, Lee MH, Au MK, Chen YL, Lu HF and Chung JG: Bufalin induces apoptosis of human osteosarcoma U2 OS cells through endoplasmic reticulum stress, caspase-and mitochondria-dependent signaling pathways. Molecules 22: E437, 2017.

35 Kasibhatla $\mathrm{S}$ and Tseng B: Why target apoptosis in cancer treatment? Mol Cancer Ther 2: 573-580, 2003.

36 Li D, Qu X, Hou K, Zhang Y, Dong Q, Teng Y, Zhang J and Liu $\mathrm{Y}$ : PI3K/AKT is involved in bufalin-induced apoptosis in gastric cancer cells. Anticancer Drugs 20: 59-64, 2009.

37 Rajoria S, Suriano R, George A, Shanmugam A, Schantz SP, Geliebter $\mathbf{J}$ and Tiwari RK: Estrogen induced metastatic modulators MMP-2 and MMP-9 are targets of 3,3'diindolylmethane in thyroid cancer. PLoS One 6: e15879, 2011.
38 Nguyen Ngoc TD, Son YO, Lim SS, Shi X, Kim JG, Heo JS, Choe Y, Jeon YM and Lee JC: Sodium fluoride induces apoptosis in mouse embryonic stem cells through ROSdependent and caspase-and JNK-mediated pathways. Toxicol Appl Pharmacol 259: 329-337, 2012.

39 Grunnet LG, Aikin R, Tonnesen MF, Paraskevas S, Blaabjerg L, Storling J, Rosenberg L, Billestrup N, Maysinger D and Mandrup-Poulsen T: Proinflammatory cytokines activate the intrinsic apoptotic pathway in beta-cells. Diabetes 58: 18071815,2009

40 Santin I, Moore F, Colli ML, Gurzov EN, Marselli L, Marchetti P and Eizirik DL: PTPN2, a candidate gene for type 1 diabetes, modulates pancreatic beta-cell apoptosis via regulation of the BH3-only protein Bim. Diabetes 60: 3279-3288, 2011.

41 Zhang H, Holzgreve W and De Geyter C: BCL2-L-10, a novel anti-apoptotic member of the BCL2 family, blocks apoptosis in the mitochondria death pathway but not in the death receptor pathway. Hum Mol Genet 10: 2329-2339, 2001.

42 Merry DE and Korsmeyer SJ: BCL2 gene family in the nervous system. Annu Rev Neurosci 20: 245-267, 1997.

43 Sano R and Reed JC: ER stress-induced cell death mechanisms. Biochim Biophys Acta 1833: 3460-3470, 2013.

44 Verfaillie T, Garg AD and Agostinis P: Targeting ER stress induced apoptosis and inflammation in cancer. Cancer Lett 332: 249-264, 2013 